\title{
Effect of Prevalent Supervisory Styles on Teaching Performance in Kuwaiti High Schools
}

\author{
Sultan G. Aldaihani ${ }^{1}$ \\ ${ }^{1}$ Department of Administration and Planning, College of Education, Kuwait University, Keifan, Kuwait \\ Correspondence: Sultan G. Aldaihani, Department of Administration and Planning, College of Education, \\ Kuwait University, PO Box 13281, Keifan, 71953, Kuwait. Tel: 965-6614-4332. Fax: 96-52-4483-8035. E-mail: \\ dr.aldaihani@gmail.com
}

Received: December 2, 2016

Accepted: January 4, 2017 Online Published: March 24, 2017

doi:10.5539/ass.v13n4p25

URL: https://doi.org/10.5539/ass.v13n4p25

\begin{abstract}
Purpose: This study sought to identify the importance of supervision in Kuwaiti high schools from the viewpoints of heads of departments and school teachers, as well as identifying the gap between ideal and prevalent supervisory styles in Kuwaiti high schools and determining the effects of supervision on teachers' professional performance. Methodology: The researcher took a qualitative approach, using structured interviews with a study sample represented by six heads of departments and six teachers from two high schools in Kuwait. Findings: It was found that supervision as a tool for continuous improvement in the school system positively affected the school climate. There was a gap between actual and ideal supervisory styles in the schools studied. Supervision had a positive effect on the professional performance of teachers; supervisors' notes and observations helped teachers in identifying their shortcomings and modifying their behavior accordingly. Challenges to the effective implementation of supervision in high schools included unsuitable supervisory practices, loss of connection between the teacher and the supervisor, teacher resistance to support, and lack of meaningful feedback. Recommendations: It is necessary to employ advanced supervisory styles in order to cope with the changes in the surrounding environment. Further study will help to determine the effect of supervision on the relationship between teachers and students.
\end{abstract}

Keywords: Kuwait, supervisory practices, instructional leadership, school reform, leadership preparation

\section{Introduction}

Teachers are the cornerstones of any educational system. In order to enable them to perform their roles, we must provide them with ample opportunity for growth and professional development. Supervision has become an essential part of the teaching profession. All educational institutions nowadays depend greatly on supervision in order to improve the instructional practices undertaken by teachers at different educational levels. Supervision can contribute significantly to the professional development of teachers by identifying their strengths and weakness.

The supervisor assumes many roles in the educational process, the most important one being that of an informative and critical consultant with the aim of improving educational outputs, helping to fulfill teachers' needs, and overcoming the various problems associated with classroom practices (Vieira, 2000). Among the many objectives of supervision in schools, the primary ones are improving the overall performance of the school and enhancing the quality of the educational process (Tesema, 2014).

Supervision can be regarded as one of the most influential factors in the quality of education, as it plays an important role in the improvement of teaching and learning by taking on the responsibility of professionally developing teachers and enhancing the academic achievement of students (Dickson, 2011).

For the supervision process to be more effective, supervisors must use appropriate strategies in the supervision of teachers in order to improve their teaching performance (Saani, 2013). Allowing for variation in supervisory styles is of great importance, as it affects the supervisees' satisfaction with the overall process. Fernando and Hulse-Killacky (2005) confirmed the correlation between supervisory styles and prediction of satisfaction with supervision as well as perceived self-efficacy of those under supervision. This study attempts to shed light on identification of different supervisory styles used by supervisors overseeing teachers in Kuwaiti high schools and 
their relative effects on professional development.

\section{Overview}

\subsection{Statement of the Problem}

The statement of the problem revolves around identifying the prevalent supervisory styles in Kuwaiti high schools and how they affect teachers professionally. Secondary schools in many countries suffer from the challenges related to academic achievement of students (Alhajeri, 2011). Many schools acknowledge the importance of using different types of supervision as a method of improving the educational process as a whole (Wolfrom, 2009). The Ministry of Education in Kuwait has responsibility for supervising both public and private sectors, except for some schools subject to control and supervision of other countries (Al-Duwaila, 2012). Kuwait has six governorates, each having its own educational district and supervisory and administrative staff (Mohammad, 2008). If we want to improve the learning outcomes and raise the quality of education, we must first delineate the different supervisory behaviors that take place in high schools in Kuwait and understand their effects on the school climate.

\subsection{Significance of the Study}

Few studies exist that aim to define common supervisory styles and identify their relationship with professional performance and development of teachers. By determining the most prevalent supervisory styles used in Kuwaiti high schools and their effects on the professional performance of teachers in Kuwait, the researcher hopes to enrich the literature regarding the most common supervisory practices in high schools in Kuwait and open the door to development of best practices in this area.

\subsection{Research Questions}

For the purposes of this study, several questions were posited:

1. How important is supervision of teachers?

2. What gap exists between ideal and prevalent styles of supervision in Kuwaiti high schools?

3. How does supervision affect teachers?

4. What difficulties do teachers encounter in their relationships with supervisors?

\subsection{Objectives of the Study}

The current study seeks to identify the perceived importance of supervision in Kuwaiti high schools from the viewpoints of both heads of departments and school teachers. It also aims at identifying existing differences between ideal and prevalent supervisory styles in Kuwaiti high schools and determining the effects of supervision on teachers' professional performance.

\subsection{Limitations of the Study}

Despite the generalizability of results the researcher seeks to achieve, this study has some limitations:

- Human Limitations: This study is limited to heads of departments and school teachers in high schools in Kuwait.

- Subject Limitation: This study is limited to a discussion of the prevalent supervisory styles in Kuwaiti high schools that affect teachers professionally.

- Time Limitations: This study is limited to the academic year 2015-2016.

\subsection{Terms Used in the Study}

\subsubsection{Supervision}

Ayodele and Oyewole (2012) have defined supervision as "an organized, democratic process involving the supervisor and the persons or groups of persons supervised, for the achievement of desired objectives" (p. 88).

\subsubsection{Supervisory Style}

Lamb (2009) has defined supervisory style as "the perception of the behaviors demonstrated by the administrators in the supervision hierarchy" (p. 139).

\section{Literature Review}

Teacher supervision has emerged as an approach to improvement in the effectiveness of teaching practices (Begum, 2008). In the preservice phase, supervising student teachers is important in preparing them for actual teaching practice (Ayodele \& Oyewole, 2012). In a study by Thobega and Miller (2008), most student teachers 
perceived value in an array of supervisory models, but found contextual and clinical supervision most helpful.

In the in-service phase, supervision is of utmost importance as it can help, stimulate, guide, and encourage growth among teachers in their efforts to improve the quality of the teaching process (Okorji \& Ogbo, 2013). Supervision helps in supporting the teaching process, assisting teachers to learn from each other, improving teacher utilization of available educational resources, and providing real opportunities for continuous evaluation and appropriate feedback (Regassa, Lemariam, Ferede, Hunde, \& Lemma, 2013).

Dickson (2011) states that supervision aims at improving the teaching and learning processes, creating a favorable atmosphere for learning, achieving synergy and coordination of efforts in a way that improves the educational outcomes, ensuring professional development of teachers, enhancing teachers' motivation, enhancing of teaching and learning quality, identifying good as well as bad traits in a teacher's practice, helping less-competent teachers to become more competent, and supporting new teachers in adapting to the school environment. The supervisor is responsible for helping teachers in selecting what goals and objectives will be implemented in the teaching process, which in fact plays an important role in motivating students and managing the classroom environment with the aim of improving the learning atmosphere (Tesema, 2014).

Traditional supervisory methods have a number of shortcomings. Typically, such methods involve a one-way direction, whereby the supervisor talks and the teacher listens. Supervision has depended on provision of notes and suggestions following lesson delivery. Suggestions given by educational supervisors represent an expression of their own viewpoints based on their observations of teachers in the classroom without input from teachers regarding the challenges they face in their daily practices with students. This type of supervision usually depends on mentoring and attempting to correct the areas of shortcomings in teachers' performance without mentioning or reinforcing areas of excellence (Dickson, 2011).

The ineffectiveness of traditional models of supervision has been demonstrated by many researchers who have found that these traditional methods cause a state of dissatisfaction among teachers. Often, the primary roles of such models have been control and inspection with limited or no intention of enhancing teachers' professional development (Wong, 2004). The traditional model was based on three rigid stages: classroom observation, scoring of lesson delivery, and writing of a report based on observation. The supervisor tended to record all the teacher's errors and shortcomings, with less emphasis on strengths (Okorji \& Ogbo, 2013).

Many factors may affect the quality of the supervision process; among these are the styles employed by the supervisor in the supervision process, which play pivotal roles in influencing the results of the supervision process (Fernando, 2003; Tanaka, 2009). Al Nazer and Mohammad (2013) revealed a statistically significant relationship between supervisors' styles and attitudes of high basic stage (middle school) teachers toward the profession. Alhajeri (2011) found a significant correlation between supervisory behaviors and school climate.

In response to the defects in the traditional style of supervision, educational researchers, school psychologists, and counselors have presented other advanced styles supervisors can adopt in order to improve the quality of the supervision process and positively affect its different outcomes (Ladany, Waljer, \& Melincoff, 2001).

Fernando (2003) compared the characteristics of three different styles of supervision: attractive, interpersonally sensitive, and task oriented. Supervisors who adopt an attractive supervisory style are characterized by flexibility, friendliness, and supportiveness. With the interpersonally sensitive style, supervisors show more investment and perceptiveness. Finally, task-oriented supervisors are more structured, purposeful, and pragmatic (Wilson, 2014). Wong (2004) showed that the most-utilized and popular supervisory style was attractive or nondirective supervision. The attractive supervisory style is best suited for supervisors who prefer a cooperative approach but don't have the time to invest in more demanding styles such as interpersonally sensitive supervision (Wong, 2004). $\mathrm{Li}(2008)$ found an association between task-oriented supervisory styles and perception of control over or ownership of a job.

The clinical supervision model is another prominent model applied to the supervision process; it depends on distinct phases: pre-conference, observation, data collection, data analysis, and reflection (see Figure 1). This model is based on effective interaction between the teacher and the supervisor in order provide teachers with feedback that is helpful in improving teachers' professional development and growth (Baltaci-Goktalay et al., 2014; Kaneko-Marques, 2015). Robinson (2000) showed that a clinical supervision style had a positive effect on the school overall performance as well as teachers' job satisfaction. 


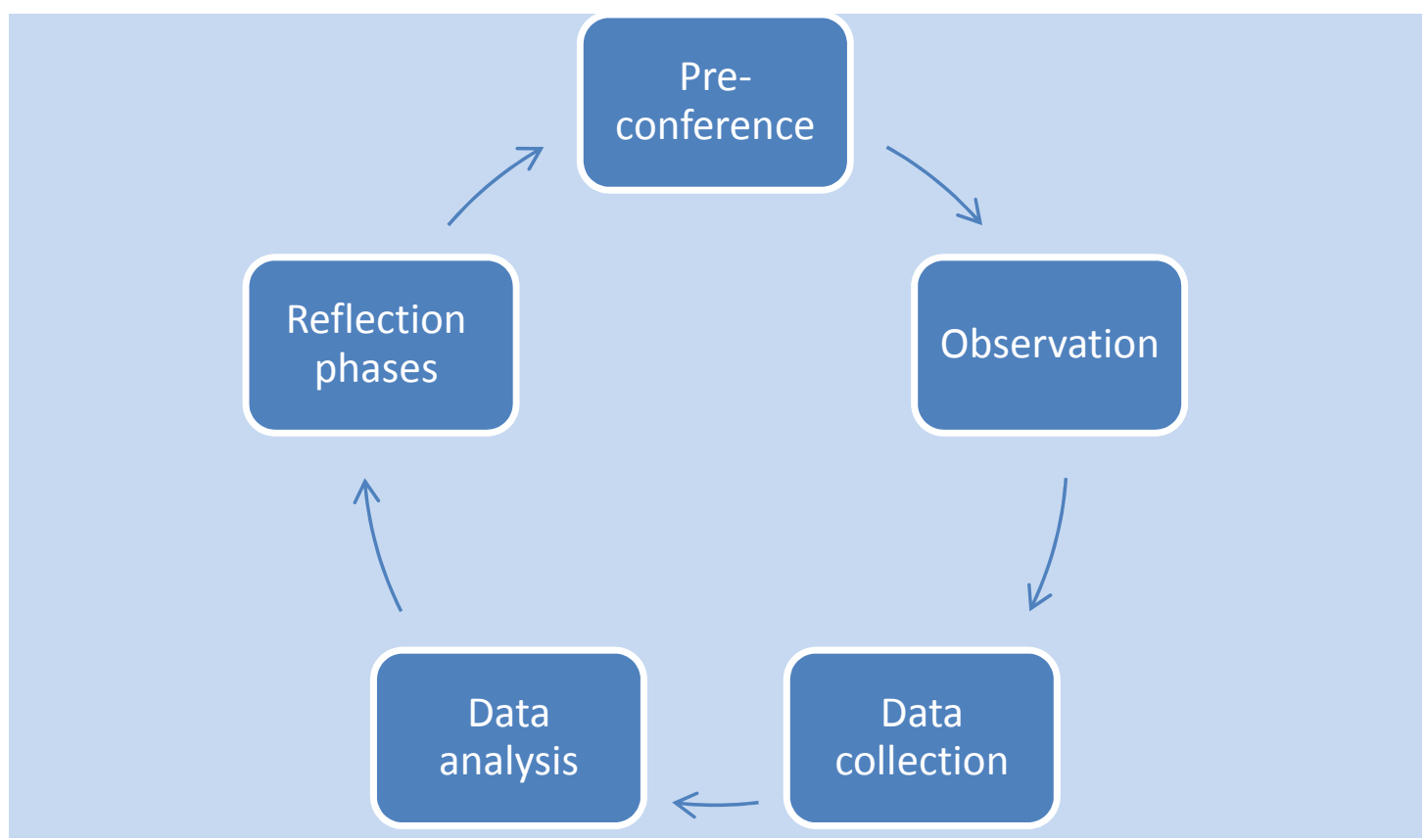

Figure 1. Clinical supervision model

Self-directed supervision is a kind of supervision in which the teachers take responsibility for their own professional development. This type of supervision is especially effective for teachers who like to work alone or have logistical or other hindrances to working with other teachers (Tesema, 2014). Self-directed supervision is based on the premise that the educational context is continually changing and teachers need to adapt to their current environment (Tesfaw \& Hofman, 2012). Similarly, in consultancy supervision, the supervisees take the responsibility for the supervision process by consulting with their supervisors as needed regarding best practices (Briggs, 2010).

Inquiry-based supervision comprises a kind of action research whereby individual teachers or teams of teachers collaborate to solve certain problems (Tesema, 2014). Human-relations supervision places an emphasis on engendering satisfaction in teachers by showing interest in them as people, with the assumption that satisfied teachers will be more productive and more open to leadership and control (Ndebele, 2013).

Sharma, Yusoff, Kannan, and Baba (2011) showed that effective and meaningful supervision depends on involving all stakeholders (e.g., teachers, principals, subject teachers, subject specialists) in the supervision process. To ensure consistent professional growth and development of teachers, supervision must be continuous. Ayodele and Oyewole (2012) revealed that to achieve sustainable development, supervisors must concentration on quality assurance.

Despite the fact that teachers understand the importance of supervision for their professional development, they are sometimes reluctant to ask their supervisors for help or additional support, which negatively affects their professional growth (Kutsyuruba, 2003). In contrast to results found by other investigators, Ndebele (2013) found that supervision lacked relevance to instructional improvement. In surveys, teachers often felt that the supervision offered lacked meaningful feedback, which could indeed relate to the use of irrelevant supervisory practices. Some educational supervisors may tend to visit the educational setting only during the final period of academic study, which doesn't reflect the real picture of teachers' performance (Ayodele \& Oyewole, 2012).

Sharma et al. (2011) found that instructional supervision directed to teachers wasn't effective as it didn't help in developing a sense of ownership or professional skills of teachers, but instead concentrated on punishing, insulting, or demoralizing teachers. Moradi, Sepehrifar, and Khadiv (2014) stated that teachers felt that they weren't being sufficiently challenged, and that the observation and feedback were only superficial. Regassa et al. (2013) concluded that problems arising with supervision stemmed from oversimplification of supervision roles by administrative offices, unwillingness of teachers to view supervisors' comments in a positive light, lack of supervisor skill in providing objective feedback, and insufficient cooperation from education offices.

Fritz and Miller (2003) stress the importance of a teacher-directed approach in supervision as an aid to 
improving outcomes by allowing adaptations consistent with the changing environment. Roffman (2007) concluded that the best models of supervision are based on reinforcement of strengths, finding such models to be stronger predictors of positive supervision outcomes than constructive focus on deficits.

\subsection{Previous Studies}

Mandell (2006) took the principal's perspective in investigating the effect of supervision on teachers' professional growth. The study sample consisted of 10 high school principals in western Pennsylvania. The study used descriptive analysis methodology and depended on a semistructured, open-ended interview format comprising 11 questions. The principals interviewed felt that supervision could affect a teacher's professional growth, but the degree of impact was dependent on the supervision model employed. The schools in this study employed two supervisory models: walkthrough and differentiated. The walkthrough model consists of observations made during short, unscheduled visits to the classroom. The differentiated model requires that the teacher select what they will be evaluated on and how they will be evaluated. Most principals in this study felt that the walkthrough model was the most effective method of helping teachers focus on instruction and improve their skills, their major consideration being the amount of time required to pursue this model effectively. The study recommended that supervision procedures and practices respect the individual differences in teachers and acknowledge the complex nature of teaching.

Erbilgin (2008) investigated an educative supervisory style, in which supervisors use open-ended questioning in conjunction with discussion of specific incidents, used by mathematics teachers in supervising student teachers. The sample used in the study consisted of three cooperating teachers and their three student teachers at a university in the southern United States. The study methodology employed mixed methods (descriptive analysis and experimental) and employed interviews, surveys of the teachers' beliefs about supervision and reflections on the program, online discussions, face-to-face meetings, observations of lessons, and post-lesson conferences as study tools. The study concluded that the program provided the supervisors with opportunities to gain new knowledge, reexamine their current beliefs, and reflect on their supervisory practices. Educative supervision places student teachers in the role of active constructors of their knowledge about teaching. The percent of talking originating with the student teachers in the post-lesson conferences increased after elucidation of the educative supervisory style being employed in the program. The study recommended that future programs provide supervisors with the opportunity to practice and discuss different types of questions, communications, and suggestions that could be employed from an educative supervision perspective.

Thobega and Miller (2008) aimed at describing student teachers' perceptions and preferences regarding the supervisory styles they experienced in working with supervisors and cooperating teachers. The study sample consisted of 72 university-level agricultural education student teachers in the United States. The study used descriptive analysis methodology and depended on a three-section questionnaire as the tool for the study. The researchers concluded that student teachers perceived that both their teachers and supervisors engaged in contextual and clinical supervision practices. Teachers generally preferred a nondirective style of developmental supervision, while supervisors tended to take a collaborative approach. Most student teachers felt that all supervision models had value, with contextual and clinical supervision being most effective. As a whole, the student teachers preferred a collaborative supervision style. The researchers recommended further study to investigate the influence of supervisor beliefs, supervisory situations, and student teachers' personal and professional characteristics on supervisory behaviors.

Khawaldeh, Al-Omari, and Al-Majali (2012) investigated supervisory beliefs of educational supervisors in the Directorate of Education in Jerash, Jordan. The study sample consisted of 24 educational supervisors in the Jerash Directorate of Education. The study used descriptive analysis methodology and employed a 40-paragraph beliefs reveal scale as the tool for the study. The study concluded that only $16.6 \%$ of supervisors were aware of their supervisory beliefs, while $83.4 \%$ of them weren't. The supervisors didn't have the necessary skills to be completely aware of their supervisory beliefs and the contradiction between belief and practice. The study recommended that supervisors be subject to training to be aware of their beliefs and to have the ability to examine them as well as the ability to analyze of the difference between perceived and actual beliefs.

Baffour-Awuah (2011) aimed to elucidate the practice of instructional supervision by examining teachers' and head teachers' concepts, perspectives, and experience with instructional supervision. The study sample consisted of 250 teachers, 50 head teachers, and 2 administrator in Ghana. The study used a mixed-method approach (descriptive analysis methodology) and employed a questionnaire, interviews, and analysis of the Ghana Education Service policy document on supervision as tools for the study. The study concluded that the policy document on instructional supervision, which emphasizes aspects of instructional supervision related to 
monitoring teaching activities and ensuring maximum use of instructional time, may have a negative impact on instructional supervision. Teachers and head teachers in this study primarily employed traditional instructional supervision practices. While the participants were for the most part satisfied with these traditional practices, they also considered that more contemporary approaches to instructional supervision should be instituted. The study recommended revision of the policy document in consultation with teachers to include more contemporary practices and including sustainable teacher and supervisor training programs in the educational budget.

Dodd (2006) investigated the differences between eastern Pennsylvania special-education administrators' perceptions of their supervisory behaviors and special-education teachers' perceptions of actual and preferred supervisory behaviors. The study sample consisted of 364 individuals (195 supervisors and 169 teachers), distributed into three groups according to experience level (1-3 years, 4-10 years, and 11+ years). The study used a descriptive comparative approach, using an electronic questionnaire to elicit teachers' and supervisors' perceptions. Dodd found that teachers with 1 to 3 years of experience preferred collaborative supervision to either directive or nondirective supervision, and teachers with 4 to 10 years of experience preferred directive supervision over nondirective or collaborative supervision; teachers with more than 10 years of experience did not differ significantly from the other two groups. Dodd concluded that experience level contributed to the mode of supervision that the teachers preferred and that was provided by their supervisors. The study recommended developing effective and efficient instruments for measuring the situational supervision model and determining if special-education teachers and supervisors had different educational needs regarding situational supervision.

Paulsen (2011) determined agriculture teachers' perceptions regarding selected instructional supervisory practices perceived to be used in supervising the performance of agriculture teachers in nonformal educational settings. The study sample comprised 234 teachers from 17 states. The study used a cross-sectional survey design with electronic questionnaires. Paulsen concluded that the general beliefs and perceptions of agricultural-education teachers toward instructional supervision did not vary significantly by age or highest degree attained. Female agricultural-education teachers embraced the importance of instructional supervision more than male teachers, as did more-experienced teachers. The study recommended that agricultural-education teachers "reinvigorate" supervised agricultural experience and formulate strategies, activities, and outcomes. It also recommended surveying principals regarding their general beliefs and perceptions regarding supervision and the importance of instructional supervisory practices.

\subsection{Comparison of Previous Studies and the Current Study}

The objective of the current study is partially consistent with Mandell (2006), who sought to determine how supervision affects teachers' professional growth; Erbilgin (2008), who aimed at understanding the ways in which a supervision program supported knowledge and practices of supervisors; Thobega and Miller (2008), who examined student teachers' perceptions and preferences regarding the type of supervision they received; and Dodd (2006), who investigated the differences between special-education supervisors' and teachers' perceptions of actual and preferred supervisory behaviors. The current study is not consistent with Khawaldeh et al. (2012), who strived to determine the awareness of supervisory beliefs in educational supervisors and Paulsen (2011), who sought to determine agriculture teachers' perceptions regarding selected instructional supervisory practices in nonformal educational settings.

The sample in this study is not consistent with any of the previous studies described, as the sample for the current study consists of heads of departments and schoolteachers, while Paulsen (2011) studied teachers; Dodd (2006) and Erbilgin (2008) studied teachers and supervisors; Baffour-Awuah (2011) studied teachers, head teachers, and administrators; Khawaldeh et al. (2012) studied supervisors; Thobega and Miller (2008) studied student teachers; and Mandell (2006) studied school principals.

The methodology of the study is not consistent with the methodology employed in the previous studies as the current study depended on qualitative methodology, while Mandell (2006), Baffour-Awuah (2011), and Khawaldeh et al. (2012) used descriptive analytic methodology; Dodd (2006) used a descriptive comparative approach; and Paulsen (2011) used a cross-sectional survey design. The study tool of the current study, interviews, is consistent with Mandell (2006), but inconsistent with Paulsen (2011) and Dodd (2006), who used electronic questionnaires; Baffour-Awuah (2011), who used a questionnaire, interviews, and document analysis; and Erbilgin (2008), who used interviews and surveys.

This researcher has benefited from previous studies in more than one area:

- reviewing the literature and documenting the references used in the study

- $\quad$ supporting the literature with results of researches and studies on the topic 
- building the statement of the problem through reviewing relevant studies

- determining the methodology and instruments of the study

- identifying appropriate statistical methods

- selecting the method to use in deducing the results of the study through analyzing the results and identifying areas of similarity and difference

\section{Study Methodology and Sample}

The researcher depended on a qualitative approach as the methodology of the study, using interviews with the study sample as represented by six male and female heads of departments and six male and female teachers from two high schools in Kuwait in order to identify viewpoints regarding the prevalent supervisory styles in Kuwaiti high schools that affect teachers professionally. Structured interviews were employed to take a closer look at the actual reality of supervisory styles used the Kuwait high school setting. The interviews revolved around four main questions:

1. From your viewpoint, is supervision considered an important issue in the school system?

2. Do you think that there is a difference between ideal and prevalent supervisory styles in Kuwaiti high schools?

3. Do you think that supervision has a positive effect on the professional performance of teachers?

4. In your actual experience, what different challenges can hinder the effective implementation of teacher supervision in school settings?

\section{Results of Interviews}

\subsection{Question 1 Responses}

The first interview question (From your viewpoint, is supervision considered an important issue in the school system?) attempted to identify the perceived importance of supervision in the school setting. Following are some of the responses. For purposes of identification, the study subjects are labeled Department Head A through D and Teacher 1 through 6.

\subsubsection{Department Head A}

"I think supervision is a basic element in all educational institutions. Its importance emerges from being a tool for continuous improvement in the school system. It positively affects the school climate."

\subsubsection{Department Head D}

"Supervision is the only way for the improvement of the school system, as it can be used as a diagnostic instrument in order to identify areas of strengths and weakness in the school performance, and thus take the necessary procedures."

\subsubsection{Teacher 1}

"Supervision is essential to my profession as a teacher. It can be regarded as a tool for continuous improvement and growth. The supervisor is responsible for identifying our needs and the needs of school principals and as a result give his opinion regarding the type and content of professional development programs."

\subsubsection{Teacher 6}

"In my opinion, school supervision is one of the means for school improvement. It helps in mentoring the progress of all individuals in the school system. It can be regarded as a tool for quality assurance."

\subsection{Question 2 Responses}

The second interview question (Do you think that there is a difference between ideal and prevalent supervisory styles in Kuwaiti high schools?) attempted to isolate the differences between ideal and actual supervisory styles employed. All the study participants agreed that there is a gap between the current and ideal supervisory styles. Following are some of the responses.

\subsubsection{Department Head C}

"I think there is a great gap between ideal and actual supervisory practices. For example, I usually prefer the clinical supervision style, but in-school supervision practiced by school principals and out-of-school supervision based on external supervisors from educational departments are a way from ideal practices." 


\subsubsection{Department Head F}

"We usually prefer self-directed supervision where we can take the responsibility of this process. I think we have knowledge and experience that can help us in doing this supervision independently, but in fact the supervisory practices are based on classroom visits only."

\subsubsection{Teacher 1}

"I can say that the current supervision process suffers from many shortcomings, as the supervisor depends on one-way direction, without any discussion of the problems facing us in the classroom, so the practice isn't effective. In my opinion, I think that clinical supervision will be an effective supervisory style through which the supervisor can determine our problems and direct us to the correct solution."

\subsubsection{Teacher 4}

"I feel a shock when talking about what is already existing and what should be existing. The ideal supervision in my opinion must be built on cooperation between the supervisee and the supervisor, but the reality is contrary to what has been mentioned, as there is no space for dialog or discussion between the two parties. The relationship is based on a supervisor who always talks and a supervisee who always listens."

\subsection{Question 3 Responses}

The third interview question (Do you think that supervision has a positive effect on the professional performance of teachers?) explored the different effects of supervision on the professional performance of teachers. All the study participants agreed that supervision has a positive effect on teachers' performance. Following are some of the responses.

\subsubsection{Department Head B}

"Supervision is one of the influential factors that does affect the professional performance of teachers. Through supervisors' notes and observations, the teacher can identify his shortcomings and modify his behavior accordingly."

\subsubsection{Department Head E}

"We can consider supervision as a method of professional development through which the teacher can get information on the advanced teaching styles, how he can control the classroom environment and deal with students, how to prepare the lesson and present it in an attractive way, and finally help teachers in making the teaching process more meaningful."

\subsubsection{Teacher 2}

"No one can deny the importance of supervision to our professional performance. If the supervisor uses the suitable supervisory style, then our performance will be improved, as the appropriate supervisory style will help in fulfilling our needs and expectations. It can guide us towards the kind of professional programs we need."

\subsubsection{Teacher 5}

"I think that the supervision process is very important for me, as it helps me to promote my teaching and behavior skills. It also provides me with the techniques through which I can improve my experiences."

\subsection{Question 4 Responses}

The fourth interview question (In your actual experience, what different challenges can hinder the effective implementation of teacher supervision in school settings?) focused on identifying the different stumbling blocks to the success of the supervision process. The responses of the study sample varied to some extent; following are some of the responses.

\subsubsection{Department Head A}

"There [are] many challenges that could affect the supervision process. Among these challenges are the use of unsuitable supervisory practices, loss of connection between the teacher and the supervisor, the unavailability of the supportive atmosphere that can help the two parties to do their best for the benefit of students.... I think the biggest challenge that can hinder the success of supervision can be represented in missing a common loop between supervisors and teachers. Also, the problem of teachers' resistance to support can be a big challenge."

\subsubsection{Teacher 2}

"The challenges that hinder the effective implementation of supervision are use of unsuitable of supervisory styles and the busy schedule of supervisors that doesn't give them the time to make the supervision process more 
meaningful."

\subsubsection{Teacher 3}

"In my opinion, there are many challenges to effective supervision. These challenges are lack of meaningful feedback, the emphasis on errors and losing sight of strengths, and failure to engage teachers in the supervision process."

\section{Analysis of Results}

\subsection{Question 1}

The study sample offered varied responses to Question 1 (From your viewpoint, is supervision considered an important issue in the school system?), but all in all, the responses confirmed that supervision is a basic element in all educational institutions. It is a tool for continuous improvement in the school system and positively affects the school climate. These results align with the conclusions drawn by Alhajeri (2011), who found significant correlation between supervisory behaviors and school climate. In addition, Tesema (2014) showed that supervision helps in improving the overall performance of a school and enhancing the quality of the educational process. As supervision can also function as a diagnostic instrument in identifying areas of strength and weakness in the school performance and helps in monitoring the progress of all individuals in the school system, it can be regarded as a quality-assurance tool.

\subsection{Question 2}

In responding to Question 2 (Do you think that there is a difference between ideal and prevalent supervisory styles in Kuwaiti high schools?) all the study participants agreed that there is a gap between actual and ideal supervisory styles in Kuwaiti high schools. The general consensus was that both on-site supervision as practiced by school principals and external supervision by administrators from educational departments at remote sites are a ways from ideal practice. Current supervisory practices are based on traditional approaches such as classroom visits. There is no space for dialog or discussion between the two parties; the relationship is based on a supervisor who always talks and a supervisee who always listens. The study sample did agree that there are tendencies toward some advanced supervisory styles, such as clinical supervision, that help teachers to identify their strengths and weakness, but expressed a need for other forms of supervision that allow the teacher to have input on the supervision process (e.g., self-directed supervision). These results are in concurrence with Robinson (2000), who showed that the use of a clinical supervision style employing feedback had a positive effect on elementary school overall performance and teacher job satisfaction.

\subsection{Question 3}

In their responses to Question 3 (Do you think that supervision has a positive effect on the professional performance of teachers?) all the study participants responded that supervision has a positive effect on teacher professional performance. Through supervisors' notes and observations, teachers can identify their shortcomings and modify their behavior accordingly. Supervision can be considered a tool for professional development with which the teacher can obtain information on advanced teaching styles and develop expertise in controlling the classroom environment, dealing with students, and preparing lessons and presenting them in an attractive way. Participants felt that when a supervisor uses a suitable supervisory style, teacher performance is improved. Further, they considered that the appropriate supervisory style could help in guiding teachers into the kinds of professional programs they needed. These results are consistent with Mandell (2006), who confirmed that supervision positively affects teacher professional growth. Additionally, Erbilgin (2008) showed that a program implementing supervision in an educational setting supported the knowledge and practices of supervisors. Thobega and Miller (2008) found all supervision models to be important, with contextual and clinical supervision being most effective.

\subsection{Question 4}

Among the challenges cited by the study sample in responding to Question 4 (In your actual experience, what different challenges can hinder the effective implementation of teacher supervision in school settings?) were the use of unsuitable supervisory practices, loss of connection between the teacher and the supervisor, lack of a supportive atmosphere that could help the administrators and teachers to do their best for the benefit of students, teachers' resistance to support, lack of meaningful feedback, emphasis on errors and losing sight of strengths, and failure to engage teachers in the supervision process. Consistent with these results, Khawaldeh et al. (2012) found that supervisors often lack the skill set that would enable them to be completely aware of their supervisory beliefs, with a resulting contradiction between belief and practice. Also, Regassa et al. (2013) in studying supervision practices in secondary schools found a failure of close cooperation between administrative offices 
and schools, lack of supervision skills in providing teachers with objective feedback, and low readiness of teachers to view positively the comments of supervisors.

\subsection{Summary}

In summary:

- Supervision is a tool for continuous improvement in the school system and positively affects the school climate.

- There is a gap between actual and ideal supervisory styles in Kuwaiti high schools in terms of both on-site supervision practiced by school principals and remote supervision by external supervisors. Current supervisory practices are based on traditional styles such as classroom visits, with no allowance made for a two-way interchange between the two parties, resulting in a relationship based on a supervisor who always talks and a supervisee who always listens.

- Supervision has a positive effect on teachers' professional performance. Through supervisor notes and observations, the teacher can identify shortcomings and modify behavior accordingly. Supervision can be utilized as a method of professional development through which the teacher can get information on advanced teaching styles and learn to control the classroom environment, deal with students, and prepare and present lessons in an attractive and effective way. With suitable supervisory styles, teacher performance can be significantly enhanced.

- Challenges typically hindering the effective implementation of supervision in high schools are unsuitable supervisory practices, loss of connection between the teacher and the supervisor, unavailability of a mutually supportive atmosphere that can help administrators and teachers to do their best for the benefit of students, teachers' resistance to support, lack of meaningful feedback, emphasis on errors and losing sight of strengths, and failure to engage teachers in the supervision process.

\section{Recommendations and Suggestions}

In the light of the results found in this study, the researcher has the following recommendations and suggestions:

- Emphasis must be placed on the importance of supervisory styles in the improvement of the educational outcomes.

- Advanced supervisory styles should be implemented to cope with the changing educational environment.

- School districts in Kuwait must work hard to provide effective training for supervisors in order to help them adopt suitable supervisory styles.

- The degree of cooperation between school teachers and supervisors in Kuwaiti high schools must be broadened.

- Further research and study should be carried out in order to investigate the effects of supervision on students' academic performance.

- The effect of supervision on the relationship between teachers and students should be determined by further study.

- The prevalent supervisory styles that affect teachers professionally at various educational levels should be identified.

\section{References}

Al-Duwaila, A. (2012). A comparative study between Kuwait's government and private sector primary schools in methods of teaching and pupils' achievement in mathematics (Doctoral dissertation, Brunel University). Retrieved from http://citeseerx.ist.psu.edu/viewdoc/download?doi=10.1.1.426.2449\&rep=rep1\&type=pdf

Alhajeri, S. (2011). Relationships between supervisory behaviors and school climate as perceived by secondary school teachers in the State of Kuwait (Unpublished doctoral dissertation). Indiana State University, Indiana, United States.

Al Nazer, M., \& Mohammad, G. H. A-R. (2013). Supervising practices of education supervisors and their relationship with the attitudes of high basic stage teachers towards the profession in the Capital Amman Governorate from their point of view. International Journal of Humanities and Social Science, 3, 223-243.

Ayodele, J. B., \& Oyewole, B. K. (2012). Towards ensuring qualitative supervision of teaching practice in Nigerian universities for sustainable development. OIDA International Journal of Sustainable Development, 5(9), 87-94. 
Baffour-Awuah, P. (2011). Supervision of instruction in public primary schools in Ghana: Teacher's and headteacher's perspectives (Professional doctorate thesis, Murdoch University). Retrieved from http://researchrepository.murdoch.edu.au/8483/

Baltaci-Goktalay, S., Kesner, J., Uzun, A., Bulunuz, N., Gürsoy, E., \& Bulunuz, M. (2014). Redefining a teacher education program: Clinical supervision model and UludagKDM. International Journal on New Trends in Education and Their Implications, 5(2), 1-11.

Begum, F. (2008). Assistant principals and teacher supervision: Roles, responsibilities and regulations. (Unpublished doctoral dissertation). University of Houston, Houston, Texas, United States.

Briggs, D. (2010). A qualitative study using interpretative phenomenological analysis to explore chartered counselling psychologists experiences of supervision (Doctoral dissertation, University of Wolverhampton. Retrieved from http://core.ac.uk/download/pdf/1933273.pdf

Dickson, A. (2011). The state of supervision of teaching and learning in public junior high schools in Ghana: A case study of selected junior high schools in Sekyere East District of Ashanti Region (Master's thesis, Kwame Nkrumah University of Science and Technology). Retrieved from http://ir.knust.edu.gh/bitstream/123456789/4048/1/Final.pdf

Dodd, R. A. (2006). Preferred supervisory practices of special education supervisors and special education teachers (Unpublished doctoral dissertation). Marywood University, Pennsylvania, United States.

Erbilgin, E. (2008). Exploring a program for improving supervisory practices of mathematics cooperating teachers (Doctoral dissertation, Florida State University). Retrieved from http://diginole.lib.fsu.edu/cgi/viewcontent.cgi?article=1435\&context=etd

Fernando, D. M. (2003). The relationship of supervisory styles to satisfaction with supervision and self-efficacy of master's level counseling students (Unpublished doctoral dissertation). University of New Orleans, Louisiana, United States.

Fernando, D. M., \& Hulse-Killacky, D. (2005). The relationship of supervisory styles to satisfaction with supervision and the perceived self-efficacy of master's-level counseling students. Counselor Education and Supervision, 44(4), 293-304. https://doi.org/10.1002/j.1556-6978.2005.tb01757.x

Fritz, C., \& Miller, G. (2003). Supervisory options for instructional leaders in education. Journal of Leadership Education, 2(2), 13-27. https://doi.org/10.12806/V2/I2/RF2

Kaneko-Marques, S. M., \& Mari, S. (2015). Reflective teacher supervision through videos of classroom teaching. Profile, 17(2), 63-79. https://doi.org/10.15446/profile.v17n2.44393

Khawaldeh, A. A., Al-Omari, J. F., \& Al-Majali, G. A. (2012). Awareness of the educational supervisors in Jordan to their supervisory beliefs (Educational supervisors in the Directorate Of Education in the Province Of Jerash) (Case Study). European Scientific Journal, 8(13), 47- 60.

Kutsyuruba, B. (2003). Instructional supervision: Perceptions of Canadian and Ukrainian beginning high-school teachers (Master's thesis, University of Saskatchewan). Retrieved from http://www.collectionscanada.gc.ca/obj/s4/f2/dsk3/SSU/TC-SSU-09052003134303.pdf

Ladany, N., Walker, J. A., \& Melincoff, D. S. (2001). Supervisory style: Its relation to the supervisory working alliance and supervisor self-disclosure. Counselor Education \& Supervision, 40(4), 263-265. https://doi.org/10.1002/j.1556-6978.2001.tb01259.x

Lamb, R. M. (2009). A social cognitive approach to collective psychological empowerment: An investigation of collective-efficacy and potency theory with technical college faculty (Doctoral dissertation, University of Georgia). Retrieved from https://getd.libs.uga.edu/pdfs/lamb_raymond_m_200912_edd.pdf

Li, T. (2008). The relationship between leadership styles, perceived control and psychological ownership (Master's thesis, University of Waikato). Retrieved from http://researchcommons.waikato.ac.nz/bitstream/handle/10289/2469/thesis.pdf? sequence=1\&isAllowed=y

Mandell, E. D. (2006). Supervisory practices and their effect on teacher's professional growth (Doctoral dissertation, University of Pittsburgh). Retrieved from http://d-scholarship.pitt.edu/6716/1/MandellEdwardDissertationMarch2006.pdf

Mohammad, E. A. A. (2008). The place of writing in first grade Kuwaiti English education: A sociological case study (Doctoral dissertation, Queensland University of Technology). Retrieved from http://eprints.qut.edu.au/26369/1/Elham_Mohammad_Thesis.pdf 
Moradi, K., Sepehrifar, S., \& Khadiv, T. P. (2014). Exploring Iranian EFL teachers' perceptions on supervision. Proceedings of the International Conference on Current Trends in ELT, 98, 1214-1223. https://doi.org/10.1016/j.sbspro.2014.03.536

Ndebele, C. (2013). Prevalent supervisory styles in primary schools in a remote rural district in Zimbabwe: Strategies for reconciling them with teacher preferred supervisory styles. Studies of Tribes and Tribals, $11(1), 55-66$.

Okorji, P. N., \& Ogbo, R. N. (2013). Effects of modified clinical supervision on teacher instructional performance. Journal of Emerging Trends in Educational Research and Policy Studies, 4, 901-905.

Paulsen, T. H. (2011). Supervisory practices in non-formal educational settings as perceived by agricultural education teachers: A national study (Doctoral dissertation, Iowa State University). Retrieved from $\mathrm{http} / / /$ lib.dr.iastate.edu/cgi/viewcontent.cgi?article=2992\& context=etd

Regassa, T., Lemariam, T. T., Ferede, B., Hunde, A. B., \& Lemma, A. (2013). An exploration of the utilization of supervision feedbacks: The case of some secondary schools in Jimma Zone. Education, 3, 309-318.

Robinson, S. G. (2000). Teacher job satisfaction and levels of clinical supervision in elementary schools (Unpublished doctoral dissertation). University of Southern Mississippi, Mississippi, United States.

Roffman, M. S. (2007). Supervisee perceptions of supervisory focus on strengths and constructive focus on deficits: Development and validation of a measure (Unpublished doctoral dissertation). University of Maryland, College Park, Maryland, United States.

Saani, A-J. (2013). Influence of compensation and supervision on private basic school teachers work performance in Ashaiman Municipality. International Journal of Business and Social Science, 4(17), 64-69.

Sharma, S., Yusoff, M., Kannan, S., \& Baba, S. B. (2011). Concerns of teachers and principals on instructional supervision in three Asian countries. International Journal of Social Science and Humanity, 1(3), 214-217. https://doi.org/10.7763/IJSSH.2011.V1.37

Tanaka, H. (2009). The relationship between supervisors' power bases and supervisory styles (Doctoral dissertation, University of New Orleans). Retrieved from http://scholarworks.uno.edu/cgi/viewcontent.cgi?article $=2006 \&$ context $=\mathrm{td}$

Tesema, A. (2014). The practices and challenges of school-based supervision in government secondary schools of Kamashi Zone of Benishangul Gumuz Regional State (Master's thesis, Jimma University). Retrieved from http://opendocs.ids.ac.uk/opendocs/bitstream/handle/123456789/5492/ABEBE\%20FINAL\%20RESEARC H.pdf? sequence $=1$

Tesfaw, T. A., \& Hofman, R. H. (2012). Instructional supervision and its relationship with professional development: Perception of private and government secondary school teachers in Addis Ababa (Master's thesis, University of Groningen). Retrieved from http://files.eric.ed.gov/fulltext/ED534226.pdf

Thobega, M., \& Miller, G. (2008). Perceptions of supervision practices by agricultural education student teachers. Journal of Agricultural Education, 49(3), 65-75. https://doi.org/10.5032/jae.2008.03065

Vieira, F. (2000). The role of instructional supervision in the development of language pedagogy. Mélanges CRAPEL, 25, 31-40.

Wilson, A. L. (2014). Reflections on the supervision interactions of residence life staff: The implications of racial identity on the hall director (HD)/resident assistant (RA) supervisory relationship (Doctoral dissertation, University of Texas at Austin). Retrieved from https://repositories.lib.utexas.edu/bitstream/ handle/2152/25229/WILSON-DISSERTATION-2014.pdf? sequence $=1$

Wolfrom, D. H. (2009). Promoting professional growth by meeting teacher needs: the walk-through as an approach to supervision (Unpublished doctoral dissertation). University of Maine, Maine, United States.

Wong, S. (2004). Pre-service teachers' perceptions of cooperative teachers' supervisory styles and satisfaction in Singapore. Educational Research Journal, 19(1), 63-91.

\section{Copyrights}

Copyright for this article is retained by the author(s), with first publication rights granted to the journal.

This is an open-access article distributed under the terms and conditions of the Creative Commons Attribution license (http://creativecommons.org/licenses/by/4.0/). 